\title{
Polish journalism: A profession (still) in transition?
}

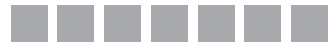 \\ Agnieszka Stępińska
}

ADAM MICKIEWICZ UNIVERSITY IN POZNAŃ, POLAND

DOI: 10.19195/1899-5101.10.1(18).3

\begin{abstract}
This paper aims at presenting the conclusions drawn from a systematic review of the studies conducted among Polish journalists since the 1970s. By comparing results of the studies on journalists with expectations and attitudes of current Polish journalism students, the paper offers an insight into the ongoing changes that have been observed among Polish journalists in the last four decades. In particular, the review revealed significant changes in a demographic profile of Polish journalists regarding gender, education, and employment, as well as their motivation to work in the profession. Furthermore, professional values of journalism in Poland have been slightly shifting from a traditional profile of a social educator and watchdog to new ones, such as a news provider.
\end{abstract}

KEYWORDS: journalists, Poland, professional roles, professional standards, students, transition, professional values.

\section{INTRODUCTION}

A traditional model of Polish journalism with a focus on political, cultural and social issues developed during the 19th century. Journalists, poets, and writers at that time saw themselves as those responsible to represent "the people without a state", support the Polish cultural and national identity and transmit them from generation to generation during 123 years of a process of divesting a Polish population of national character by the invaders (Russian Empire, Kingdom of Prussia and Habsburg Austria) that conducted three so-called "Partitions" of Poland in the 18th century (Łojek et al., 1988). This model was further strengthened during the Second World War: despite the Nazi occupation of the country, about 2,000 illegal Polish underground newspapers and magazines were circulated between 1939 and 1945 (Lewandowska, 1982).

The post-war period of the Polish media was again characterized by a strong political dependence, this time on the Soviet Union. Polish journalists experienced censorship and political repression that was based on the communist idea of a stateowned media. While some journalists agreed to cooperate with the regime, others decided to join illegal newspapers and magazines that were launched in the 1970s 
(Dziki, 2000). Regardless the represented ideology, Polish journalists viewed themselves as social educators, with a strong sense of the political nature of their jobs, guided more by the consideration of their social mission as defined by their political sponsors than by a story's attractiveness for the audience (Jakubowicz, 1992).

The period of the last 25 years can be described as a period of political and economic transformation and a consolidation that has been leading to "Western type democratic societies" (Balcytiene et al., 2014, p. 13). The role of the media was crucial in the transition process since they served as a forum of political and social debate over the future shape of the relations between the state and society. The media themselves experienced a transformation from a state-owned system to a dual model with private and public electronic media accompanied with a free market of printed media, followed by a technological transformation that started in 1995.

This paper aims at providing answers to the following research questions: (RQ1) How has the demographic profile of the Polish journalist changed in the last four decades? (RQ2) Has there been any shift in motivation for working as a journalist since the communist regime period? (RQ3) Did the transformation affect a role perception among Polish journalists? To achieve that goal, we collected and systematically reviewed findings of the surveys that have been conducted among Polish journalists since the 1970s. Then, we compared them with results of recent studies on expectations and attitudes of current Polish journalism students.

Two consecutive parts of the paper will be devoted to present studies under the review and their theoretical backgrounds. Although the methodology used in these studies differs, they are based on the same models of journalism and they share an interest in similar aspects of the journalistic profession, including journalists' attitudes and role perception.

\section{SURVEYS AMONG POLISH JOURNALISTS AND JOURNALISM STUDENTS}

From the 1970s till 2000 empirical studies on Polish journalists have been conducted by scholars working at the Press Research Center (Ośrodek Badań Prasoznawczych) in Cracow (Pisarek, 1995, 1998; Bajka, 1991, 2000). The questionnaires used in these studies included questions on demographic profile (age, gender, education), motivation for working as a journalist, level of autonomy, as well as on evaluation of the media performance. In the 1970s and 1980s similar studies were conducted by Jane L. Curry (1980, 1990), an American scholar who was interested in professional training, organization and relations between Polish journalists and politicians, especially during the period of martial law.

In that paper we collect and review findings of six aforementioned studies: three studies on journalists conducted by the Ośrodek Badań Prasoznawczych (Press Research Center) in the years 1979, 1990, and 2000, a study conducted by Stępińska and Ossowski in 2009, a study conducted by Dobek-Ostrowska et al. in the years 20112014, and one study on journalism students conducted by Stępińska et al. in 2014. 
The early empirical studies conducted by the Ośrodek Badan Prasoznawczych (Press Research Center) were collected and reported by Bajka in 1991 and 2000. In the former paper there is no information about the sample. In 2000 Bajka surveyed a group of 250 journalists who, actually, cannot be perceived as fully representative, due to the fact that a category of young journalists holding lower positions at the media organizations was oversampled. Namely, 53 percent of the respondents were people under 30 years old, while only 6 percent were journalists above 50 years old (Bajka, 2000, pp. 47-48). Consequently, the results of that study do not draw a picture of Polish journalists in general, but rather of a new generation of journalists, who entered the profession at some point in the previous decade ( 80 percent of respondents reported that their professional experience was less than 10 years).

In the 1990s and 2000s some of the studies were conducted under the framework of international projects. For example, Olędzki (1998) participated in the project "The Global Journalist" launched and coordinated by David H. Weaver. A decade later, when a second edition of that international research initiative ("The Global Journalist in the 21st Century") was launched by David H. Weaver and Lars Willnat (2012), a survey among Polish journalists was conducted by Agnieszka Stępińska and Szymon Ossowski (2010a, 2010b, 2011a, 2011b, 2011c, 2012; Stępińska et al., 2012; Stępińska \& Głowacki, 2014). Polish data came from 329 telephone interviews that were conducted with a random sample of Polish journalists in October and November 2009.

In order to design the sample, we decided to compile first a list of all Polish news organizations with the help of the most recent Media and Advertising Almanac (Almanach Mediów i Reklamy 2007/2008). Based on the compiled list, we estimated that 12 percent of Polish journalists work for daily newspapers, 23 percent for weekly magazines, 23 percent for monthly magazines, 1 percent for news agencies, 15 percent for TV stations, 17 percent for radio stations, and 8 percent for the online media.

In the previous decade, Polish scholars also participated in such international projects as: "Media Accountability and Transparency in Europe MediaAcT" (Głowacki, 2013) and "Journalism in change - professional journalistic cultures in Russia, Poland and Sweden 2011-2014" (Dobek-Ostrowska et al., 2013; Nygren \& Dobek-Ostrowska, 2015). The former was conducted among 100 Polish professionals who were occupied full-time or almost full-time (including the requirement of 50 percent or more of income from journalistic activity) and working for different media segments, including newspapers, magazines, radio, TV, press agencies and online news media. In the latter, the survey was conducted among 500 Polish journalists in 2012. Again, the sample was designed based on the data from the Media and Advertising Almanac (2011/12) and with reference to different media segments and employment structure (full-time salaried employees and freelancers).

More recently (November and December 2014) a survey was conducted among Polish journalism students from six public (state) universities and one private uni- 
versity. The survey was a part of the an international project "Journalism Students around the Globe" launched and coordinated by Folker Hanusch from University of Vienna (Austria). and Claudia Mellado from Pontificia Universidad Catolica de Valparaiso (Chile). As many as 43 national teams have been participating in that project. ${ }^{1}$ In Poland the study was conducted by scholars from the Adam Mickiewicz University in Poznań: Agnieszka Stępińska, Dominika Narożna, Ewa Jurga-Wosik, Bartłomiej Secler, and Kinga Adamczewska.

The universities were selected among those offering a program of Journalism and Social Communication based on their location (six cities: Warszawa, Poznań, Wrocław, Lublin, Kraków, and Katowice) and a number of students. A total number of students interviewed $(\mathrm{N}=602)$ depended on three parameters: population size, confidence level (95 percent) and the amount of accepted sampling error (4 percent). We collected information about numbers of students at seven selected universities and we used a probability-proportional-to-size sampling. Students across the various years of a degree were selected randomly and requested to complete a self-administered questionnaire.

\section{THEORETICAL BACKGROUND}

The systematic review of the aforementioned studies and their findings revealed that they were designed based on normative or empirical theories of journalism developed in the last three decades. All these concepts are interrelated: in fact, they have been consecutively emerging from previous ideas and models.

While studying motivations and professional role performance they all follow Culbertson's concept (1983) and distinguish three main attitudes among journalists: (1) neutral, stressing fact accuracy and speed; (2) interpretative, incorporating social science and historical research to study every aspect of the events and their meanings; (3) activists, or proactive reporting with a list of prescriptions to correct the illness of society.

They also employ Weaver and Wilhoit's (1996) distinction of four main media roles, that is (1) a disseminator (getting information to the public quickly and avoiding stories with unverifiable information), (2) interpretative/investigative (investigating government claims, analyzing and interpreting issues and discussing public policy while it is being developed), (3) adversarial (being constantly skeptical of government and businesses), and (4) a populist mobilizer (developing the cultural interests of the public, providing entertainment, setting the political agenda and giving ordinary citizens a chance to express their views). Although that typology was developed based on the US experience, it served as a theoretical background for studies of journalists in many other countries, including Poland, conducted under two international projects: "The Global Journalist" and "The Global

\footnotetext{
1 See: http://www.jstudentsproject.org/.
} 
Journalist in the 21st Century" (Weaver, 1998; Olędzki, 1998; Weaver and Willnat, 2012; Stępińska et al., 2012).

In more recent studies a concept of journalistic cultures developed by Hanitzsch (2007) has been used. For example, it was employed in the project "Journalism in change - professional journalistic cultures in Russia, Poland and Sweden 20112014 " in order to identify common parts of transnational journalistic culture, general changes in journalism in different media systems, as well as differences between the three countries (Nygren \& Dobek-Ostrowska, 2015).

Journalistic culture emphasizes not only values, attitudes and beliefs (perception or conception), as the previous concepts did, but also practices and artifacts (performance). Hanitzsch (2007) defines three constituents of journalistic culture: institutional roles, epistemologies, and ethical ideologies, as well as three basic dimensions of the journalists' role performance: (1) interventionism, (2) power distance, and (3) market orientation. As a result, he distinguishes four main models of journalism: (1) a detached watchdog (interested in providing the audience with political information, high distance towards power political elites, skeptical and critical attitude); (2) populist disseminator (strong orientation towards the audience, focus on providing the audience with "interesting" information, low level of interventionism); (3) critical change agent (driven by interventionist intentions, critical towards government and business elites, emphasis on advocating social change, influencing public opinion or setting the political agenda); and (4) opportunist facilitator (constructive partners of the government, support for official policies, close distance to political powers).

Alongside that concept, Mellado (2015; see also Mellado \& Lagos, 2014) suggested a concrete operationalization of six dimensions of journalistic role performance that emerge from three different domains that have been discussed by previous literature (Donsbach \& Patterson, 2004; Weaver \& Wilhoit, 1996): (a) the relationship journalism has with those in power (watchdog versus loyal-facilitator), (b) the presence of the journalistic voice in a story ( disseminator-interventionist dimension), and (c) the way journalism approaches the audience (three approaches toward the audience: service - audience as clients, infotainment - spectators, and civic-oriented journalism - citizens). Each one of these dimensions is characterized by different measures of professional practice. The concept was employed in the international projects on "Journalistic Role Performance Around the Globe" and "Journalism Students around the Globe".

While presenting the findings of the studies we will use the concept introduced by Weaver and Wilhoit (1996) because it might be perceived as a benchmark for the other aforementioned ideas and models.

\section{CHANGES IN A DEMOGRAHIC PROFILE}

In the late 1970s the total number of Polish journalists was 8,200. Around 14 percent of them worked for TV and radio stations. In the 1980s an estimated number 
of journalists was higher $(9,600-10,000)$, with around 10 percent of journalists working for the electronic media (Bajka, 1991, p. 149). Political transition caused serious consequences for Polish journalism, including a generation change, or as Sonczyk (2001, p. 40) called it: a "personnel revolution". In three years (1989-1992) about 1,500 journalists left or lost their jobs (Bajka, 2000, p. 45). Among them there were those who previously supported the communist regime and those who were not able to respond to technological challenges (mostly, the elder journalists) (Bajka, 1991, p. 149). Some journalists experienced difficulties in adapting themselves to the market-oriented expectations of the media owners, while the others suffered from a political and social disorientation (Bajka, 2000, pp. 44-45).

Despite the outflow, the number of professional journalists increased from 10,000 (in the 1980s) to 12,000 in the late 1990s (Bajka, 1991, p. 149), because a new generation of journalists entered the profession. Some of them had previously worked for the underground anti-regime newspapers and magazines, while the others were young people who just recently graduated from universities, having little professional experience and no interest in political involvement (Bajka, 2000, pp. 44-46). In 2012 the estimated number of full-employed journalists was again lower, around 9,100, while around 900 journalists worked as freelancers (DobekOstrowska et al., 2013, p. 14).

The structure of employment has changed as well in recent decades. Before 1989, most journalists belonged to the salaried, full-time media personnel (Bajka, 1991, p. 149). Two decades later Stępińska and Ossowski (2011b) found that more than 20 percent of journalists overall, and almost 60 percent of TV professionals, were contract workers. Most of them have either time-limited contracts or operated as separate media producers offering their work to TV stations. What makes this form of employment so popular among media organizations is the fact that journalists rather than the employers have to cover the costs of social and health insurance. Findings of the study conducted by Dobek-Ostrowska et al. (2015) confirmed that structure of employment: 67 percent of the respondents were fully-employed in the media organizations, 11 percent were part-time employees and 13 percent were freelancers (Dobek-Ostrowska et al., 2013; Głowacki, 2015, p. 79).

Since the 1970s the number of female journalists has increased. In the 1970s around one quarter of Polish journalists were female. Three decades later women made up 35 percent of Polish journalists (Bajka, 2000, p. 46). Findings of the studies conducted in 2009 and 2012 revealed that the number of female journalists has increased in the last ten years: around 40 percent of respondents in these studies were female (Stępińska \& Ossowski, 2011b, p. 19; Dobek-Ostrowska et al., 2013, p. 15; Głowacki, 2015, p. 67).

The other significant change has occurred in the education sector. Since the late 1990s one may observe a clear trend toward "academization" (Splichal \& Sparks, 1994; Hanusch \& Mellado, 2014) of Polish journalism. Until the 1990s most universities offered only a specialization in journalism as a part of the program in 
political science, in 2009 the media or journalism studies were offered by 42 public and private universities in Poland as separate programs of study (Olszewski, 2009).

In 2000, as Bajka (2000, pp. 48-49) showed, 45 percent of Polish journalists graduated from any program in journalism (11 percent at the BA level, 24 at the MA level, and 10 percent at the postgraduate level, while 8 percent were still students of journalism at that time). One third of the respondents graduated from some other program than journalism (social sciences, humanities, or other disciplines), while only 14 percent of the respondents did not graduate from any university program. A decade later, the number of journalists who graduated from any university program was higher: as many as 84.2 percent of Polish journalists held a university degree, at least at the undergraduate level. However, fewer journalists, namely 31.6 percent, held a university degree in journalism (Stępińska \& Ossowski, 2011b, p. 19). In 2012 as many as 89 percent of journalists held any university degree, and 40 percent of the respondents declared that they held a university degree in journalism (Głowacki, 2015, p. 74).

In 2013 as many as 18,832 people were students of the Journalism and Social Communication program (GUS, 2013). The results of the recently conducted survey among students of that program showed that 22 percent of those who have chosen that program "absolutely" wanted to pursue a career as a journalist, 27.5 percent: "likely", 27.8 percent was still unsure, while 7.5 percent definitely did not want to work as a journalist and for 15.1 percent of the respondents it was "unlikely". At the same time, only 9.6 percent of the students "very much agreed" with a claim that studying journalism and communication at the university level is necessary in order to be a good journalist, while 20.6 "very much disagreed" with that claim. Still, 35.9 percent "somewhat agreed", while 33.7 percent "somewhat disagreed" with such a statement.

\section{CHANGES IN THE MOTIVATIONS FOR WORKING AS A JOURNALIST}

In the late 1970 journalists declared that they entered the profession because they wanted to have varied and lively work (25 percent), where they could still learn something new (36 percent) and they wanted to help people solve their problems (33 percent). Almost one third of the respondents (31 percent) believed that they would have a chance to criticize and fight with shortcomings or problems (Bajka, 1991, pp. 157-158). The journalists of the late 1980s and of the 1990s appreciated the most the dynamic lifestyle and varied and lively work, and the fact that journalism provides them with an opportunity to meet interesting people and visit new places. At the same time, they less frequently than earlier generations expected having an opportunity to influence people's opinions and attitudes, or help people solving their problems (Bajka, 2000, pp. 52-53). The comparison of the data collected in two decades by Bajka $(1991,2000)$ showed that Polish journalists have 
become more individualistic-oriented and less driven by social, altruist motivations.

Table 1. Motivations for working as a journalist/studying journalism (a sum of percent of answers "very important" and "important")

\begin{tabular}{|c|c|c|c|c|c|}
\hline \multicolumn{5}{|c|}{ JOURNALISTS } & STUDENTS \\
\hline 1979 & 1990 & 2000 & 2009 & 2012 & 2014 \\
& & $(\mathrm{~N}=250)$ & $(\mathrm{N}=329)$ & $(\mathrm{N}=100)$ & $(\mathrm{N}=602)$ \\
\hline
\end{tabular}

\begin{tabular}{|l|c|c|c|c|c|c|c|}
\hline PRACTICAL \\
\hline $\begin{array}{l}\text { The amount of money one can } \\
\text { earn }\end{array}$ & - & - & - & 67 & 74 & 57 \\
\hline To get a secure job & - & - & - & 61 & 63 & 68.4 \\
\hline The amount of autonomy & - & - & - & 86 & 83 & 81 \\
\hline PERSONAL & 9 & 10 & 16 & - & - & 50 \\
\hline $\begin{array}{l}\text { The prestige of journalism } \\
\text { as a profession }\end{array}$ & 17 & 43 & 56 & - & - & 55 \\
\hline The opportunity to travel & 36 & 33 & 43 & 79 & - & 74 \\
\hline The varied and lively work & 25 & 36 & 33 & - & - & 63 \\
\hline The dynamic lifestyle & 33 & 26 & 21 & 65 & 74 & 68 \\
\hline IDEALISTIC & 25 & 29 & 58 & 59 & 62 \\
\hline $\begin{array}{l}\text { The chance to influence public } \\
\text { affairs }\end{array}$ & 26 & 15 & 23 & - & 74 & 60 \\
\hline $\begin{array}{l}\text { The chance to help people } \\
\text { in their everyday life }\end{array}$ & 31 & & & & \\
\hline $\begin{array}{l}\text { To criticize and fight problems } \\
\text { (e.g. injustice) }\end{array}$ & 31 & & & & \\
\hline
\end{tabular}

Source: Bajka (2000, p. 52); Stępińska et al. (2012, pp. 262-263); Dobek-Ostrowska et al. (2013, p. 18); Project "Journalistic Performance Around the Globe" (2014).

Table 1 collects responses to the question on motivations for working as a journalist $(1979,1990,2000)$ or studying journalism (2014), as well as an importance of various aspects of the job (2009 and 2012). The results showed that in 2009 job autonomy and a chance to develop professional skills were considered very important by a vast majority of journalists, namely more than 80 percent. For more than 60 percent of journalists, not only are pay and job security very important, but also the chance to help people and the editorial policy of the organizations (see also: Stępińska et al., 2012, p. 262).

Similar conclusions may be drawn from the study conducted by Dobek-Ostrowska et al. (2013) a few years later. When asked about the evaluation of aspects of their work, most journalists indicated as "very important" and "important" such issues as: a chance to develop their professional skills (85 percent), level of auton- 
omy (83 percent), and atmosphere of the workplace ( 82 percent), as well as a chance to help people (74 percent). Issues such as a chance to influence public affairs (59 percent), or fringe benefits ( 42 percent) seemed to be less important for them.

Table 2 collects again the answers to the question on the motivations (from the three most recent studies), but this time it shows means and SD (answers on a scale $1-5$ where 5 is very important, $1-$ not important).

Table 2. Factors influencing job choice

\begin{tabular}{|c|c|c|c|c|c|c|c|c|c|}
\hline & \multicolumn{3}{|c|}{ JOURNALISTS (2009) } & \multicolumn{3}{|c|}{ JOURNALISTS (2012) } & \multicolumn{3}{|c|}{ STUDENTS (2014) } \\
\hline & $\mathrm{N}$ & $M$ & SD & $\mathrm{N}$ & $M$ & SD & $\mathrm{N}$ & $\mathrm{M}$ & SD \\
\hline \multicolumn{10}{|l|}{ PRACTICAL } \\
\hline Salary & 329 & 4.3 & 1,234 & 499 & 4.1 & 0.818 & 593 & 3.9 & 1.007 \\
\hline Benefits & 329 & 3.6 & 1.664 & 480 & 2.9 & 1.203 & - & - & - \\
\hline Editorial policy & 329 & 4.3 & 1.576 & 454 & 3.9 & 1.153 & - & - & - \\
\hline Job security & 329 & 4.0 & 1.516 & 450 & 3.9 & 1.205 & 593 & 3.1 & 1.171 \\
\hline \multicolumn{10}{|l|}{ PERSONAL } \\
\hline $\begin{array}{l}\text { Chance to develop profes- } \\
\text { sional skills/specialization }\end{array}$ & 329 & 4.5 & 1.131 & 476 & 4.5 & .804 & - & - & - \\
\hline $\begin{array}{l}\text { Chance for a better career/ } \\
\text { to get ahead in organiza- } \\
\text { tion }\end{array}$ & 329 & 3.4 & 1.622 & 468 & 4.2 & .963 & - & - & - \\
\hline \multicolumn{10}{|l|}{ IDEALISTIC } \\
\hline $\begin{array}{l}\text { Autonomy (freedom in the } \\
\text { job) }\end{array}$ & 329 & 4.7 & .786 & 475 & 4.4 & .797 & 591 & 4.1 & .882 \\
\hline $\begin{array}{l}\text { The chance to help people/ } \\
\text { serve the public interest }\end{array}$ & 329 & 4.3 & 1.267 & 476 & 4.2 & .995 & 589 & 3.8 & 1.134 \\
\hline $\begin{array}{l}\text { The chance to influence } \\
\text { public affairs/society }\end{array}$ & 329 & 4.0 & 1.296 & 468 & 3.8 & 1.088 & 587 & 3.5 & 1.036 \\
\hline
\end{tabular}

Source: Project: "Global Journalists in the 21st Century" (2009); "Journalism in change — professional journalistic cultures in Russia, Poland and Sweden 2011-2014" - see Anikina (2015, p. 154); Project: "Journalistic Role Performance Around the Globe" (2014).

The factor evaluated highly by respondents in all three studies was the amount of autonomy or freedom in the job. For professional journalists a chance to develop professional skills (2009) or a specialization (2012), as well as salary seem to be very important aspects of the job. For students, however, the leading factors were those related rather to choice of the program of the study (Journalism and Social Communication) than a job: a talent for journalism $(\mathrm{M}=4.2, \mathrm{SD}=.805)$ and an ability to be creative $(\mathrm{M}=4.2, \mathrm{SD}=.794)$.

Findings of the study on students' motivations provided further arguments on the individualistic approach to the profession among the young generation. They 
seem to be less motivated by social or political aspects of the job, such as a chance to help people/serve the public interest or a chance to influence public affairs/society than professional journalists. Furthermore, opportunities of travelling $(M=3.4$, $\mathrm{SD}=1.167)$, having varied and lively work $(\mathrm{M}=3.9, \mathrm{SD}=1.002)$, and meeting interesting people $(\mathrm{M}=4.2, \mathrm{SD}=.947)$ are more appealing for them than a chance to help in a nation-building $(\mathrm{M}=2.9, \mathrm{SD}=1.232)$, work for freedom and democracy $(\mathrm{M}=3.0, \mathrm{SD}=1.156)$, or hold power people accountable $(\mathrm{M}=2.8, \mathrm{SD}=1.177)$.

Although students stress salary as a quite meaningful aspect of the job $(\mathrm{M}=3.9$, $\mathrm{SD}=1.007)$, they are not equally tempted by being famous $(\mathrm{M}=2.45, \mathrm{SD}=1.129)$. Furthermore, the amount of money one may earn is almost equally important for them as the pleasure of writing $(\mathrm{M}=3.8, \mathrm{SD}=1.187)$.

The findings correspond with observations on differences between generations of Polish professional journalists. As the studies showed (Stępińska \& Ossowski, 2012; Stępińska \& Głowacki, 2014; Anikina, 2015), the youngest journalists (20-30 years old) were more interested than other age categories in an opportunity to develop professional skills, a chance to get ahead in the media organization, and job security. At the same time, they were less interested in such professional aspects as editorial policy and amount of autonomy. Clearly, they were more focused on their own individual careers than on organizational affairs. On the contrary, the elder generation of journalists (50+) and those who have been holding positions in media organizations for more than 20 years seemed to pay significant attention to the organization and its policy, as well as to the level of freedom in selecting stories. Journalists over 60 years old paid attention mostly to the professional "institutional" aspects of the job. These journalists do not have to worry about their position, promotion or even pay. Instead, they consider themselves as those who could influence public affairs and help people.

\section{CHANGES IN THE ROLE PERCEPTION}

In the late 1970s and early 1980s Polish journalists were still experiencing the communist party's attempts of instrumentalization of the media. Despite the political context, Polish journalists did not share a number of characteristics with the Soviet states' journalists at that time. In fact, they were able to develop a strong professional culture, as Curry $(1980,1990)$ noticed. In 1980-1981 journalists explicitly expressed their resistance from playing a role of political actors, while still accepting partnership relations with the political party in power (Bajka, 1991, pp. 153-154).

At that time, Polish journalism had been shifting quickly towards an information-oriented model during that period: more and more journalists claimed that they should be more critical and less focused on propaganda. While in 1979 around 75 percent of journalists pointed objective reporting as a main function of the media, just two years later almost all respondents (98 percent) of Bajka's (1991, p. 154) study claimed that the media should be objective in the reporting on do- 
mestic and foreign events, 94 percent of journalists claimed that the media should provide information about citizens' demands (in comparison to 65 percent in 1979), and 87 percent expressed the opinion that the media should provide a complete and comprehensive picture of political and administrative actors (65 percent in 1979).

A decade later Polish journalists defined their roles mostly as objective reporters of domestic and foreign events ( 33 percent of the respondents evaluated that role as "very important", while 66 percent as "the most important"), as well as a watchdog: a highly critical political actors' adversary (81 percent of responses "very important", 14 percent of "the most important"), who provides the citizens with a complete picture of the political elites (77 and 10 percent, respectively). Furthermore, Polish journalists in the early 1990s claimed that the media should fight with social problems (81 and 11 percent, respectively), and provide the political elites information about citizen' demands: for 69 percent of the respondents it was a "very important" role of the media, while for as many as 22 percent - "the most important" one (Bajka, 1991, p. 154).

At the same time, Polish journalists claimed that the media should not popularize political and social organizations' activities (46 percent of respondents claimed that this was "not an important" role of the media), mobilize citizens to work hard (51 percent of the indications of the "not important" response), and 61 percent claimed that they are not interested in involving the audience into politics (Bajka, 1991, p. 154). In just one decade the conception of journalistic roles has changed significantly: from the political-oriented to the society-oriented media and journalists.

Based on the aforementioned results, Pisarek (1998) recognized three main Polish journalists' roles and attitudes at that time: (1) ideological fighters, whose political orientation affects the way they present political, economic and social issues; (2) disc jockeys, who represent a model of infotainment journalism, and (3) craftsmen who obey professional norms and standards and who perceive their job as a social mission. Bajka (2000, pp. 59-60) added three more roles to that list: (4) waiters, who focus mostly on a quick dissemination of the news and do not provide any comments, interpretations, or framing; (5) investigators, who focus on investigating government claims, analyzing and interpreting issues and discussing public policy while it is being developed. However, they are politically biased and their interest in political actors depends on their political orientation (Bajka, 2000, p. 60). Finally, Bajka (2000, p. 60) recognized so called (6) news gatherers, whose main role is to collect information, either from news agencies or other media sources, including the online media and then deliver them to the media organizations or the audience.

The first decade of the 21st century brought again a slight shift toward news provider model of journalism (getting information to the public quickly, be a neutral reporter). Still, journalists perceived their role as a detached watchdog (being an adversary of public officials by being constantly skeptical of their actions) and educator (developing intellectual and cultural interests of the public and providing an- 
alysis and interpretation of complex problems). However, some incoherence might be observed within the adversarial (watchdog) model: a general concept of being an adversary of public officials and control public authorities seem to be more important than more practical aspects of the same role, that is investigating claims and statements made by the government (Table 3 presents means and standard derivation; the answers on a scale $1-5$, where 5 is very important, $1-$ not important).

Table 3. Importance of the media functions according to Polish journalists (2009 and 2012) and students of journalism (2014)

\begin{tabular}{|c|c|c|c|c|c|c|c|c|c|}
\hline & \multicolumn{3}{|c|}{$\begin{array}{l}\text { JOURNALISTS } \\
\text { IN } 2009\end{array}$} & \multicolumn{3}{|c|}{$\begin{array}{l}\text { JOURNALISTS } \\
\text { IN } 2012\end{array}$} & \multicolumn{3}{|c|}{$\begin{array}{l}\text { JOURNALISM } \\
\text { STUDENTS } \\
\text { IN } 2014\end{array}$} \\
\hline & $\mathrm{N}$ & $\mathrm{M}$ & SD & $\mathrm{N}$ & $M$ & SD & $\mathrm{N}$ & $\mathrm{M}$ & SD \\
\hline \multicolumn{10}{|l|}{ DISSEMINATOR } \\
\hline $\begin{array}{l}\text { Get information to the } \\
\text { public quickly }\end{array}$ & 329 & 4.6 & 1.019 & - & - & - & 594 & 4.2 & 1.251 \\
\hline $\begin{array}{l}\text { Report things as they are/ } \\
\text { be a neutral reporter }\end{array}$ & - & - & - & 493 & 4.2 & .913 & 577 & 4.4 & 1.263 \\
\hline \multicolumn{10}{|l|}{ ADVERSARIAL } \\
\hline $\begin{array}{l}\text { Be an adversary of public } \\
\text { officials/control public } \\
\text { authorities }\end{array}$ & 329 & 4.4 & 1.472 & 487 & 4.4 & .754 & 595 & 4.5 & 1.601 \\
\hline $\begin{array}{l}\text { Investigate claims and } \\
\text { statements made by the } \\
\text { government }\end{array}$ & 329 & 3.6 & 1.717 & 484 & 3.1 & 1.123 & 594 & 3.4 & 1.680 \\
\hline \multicolumn{10}{|l|}{ INTERPRETATIVE } \\
\hline Set the political agenda & 329 & 4.2 & 1.380 & - & - & - & 592 & 3.8 & 1.622 \\
\hline $\begin{array}{l}\text { Develop intellectual and } \\
\text { cultural interests of the } \\
\text { public/educate the public }\end{array}$ & 329 & 4.4 & 1.138 & 489 & 4.3 & .828 & 592 & 4.2 & 1.279 \\
\hline $\begin{array}{l}\text { Provide analysis and } \\
\text { interpretation of complex } \\
\text { problems. }\end{array}$ & 329 & 4.3 & 1.336 & 490 & 4.0 & .885 & 595 & 4.0 & 1.226 \\
\hline $\begin{array}{l}\text { Provide advice/solutions } \\
\text { to society's problem. }\end{array}$ & 329 & 4.2 & 1.493 & - & - & - & 596 & 3.6 & 1.314 \\
\hline \multicolumn{10}{|l|}{ POPULIST MOBILIZER } \\
\hline Influence public opinion & - & - & - & 482 & 3.5 & 1.004 & 593 & 3.9 & 1.437 \\
\hline $\begin{array}{l}\text { Give ordinary people } \\
\text { a chance to express their } \\
\text { views on public affairs/ } \\
\text { represent diverse social } \\
\text { groups }\end{array}$ & 329 & 4.0 & 1.366 & 481 & 4.2 & .920 & 598 & 4.0 & 1.287 \\
\hline
\end{tabular}




\begin{tabular}{|l|c|c|c|c|c|c|c|c|c|}
\hline $\begin{array}{l}\text { Motivate ordinary people } \\
\text { to get involved in public } \\
\text { discussions of important } \\
\text { issues. }\end{array}$ & 329 & 4.0 & 1.455 & 487 & 4.0 & .936 & 591 & 3.5 & 1.740 \\
\hline $\begin{array}{l}\text { Provide entertainment } \\
\text { and relaxation. }\end{array}$ & 329 & 3.3 & 1.633 & 480 & 4.2 & .845 & 593 & 3.6 & 1.311 \\
\hline $\begin{array}{l}\text { Concentrate on news that's } \\
\text { of interest to the widest } \\
\text { possible audience. }\end{array}$ & 329 & 4.1 & 1.366 & - & - & - & 596 & 3.8 & 1.478 \\
\hline
\end{tabular}

Source: Project: "Global Journalists in the 21st Century" (2009); "Journalism in change — professional journalistic cultures in Russia, Poland and Sweden 2011-2014" - see Anikina (2015, p. 169); Project: "Journalistic Role Performance Around the Globe" (2014).

Roles related closer to a populist mobilizer model of journalism (or the indicators to the civic model, according to Mellado), such as giving ordinary people a chance to express their views on public affairs, or motivating ordinary people to get involved in public discussions of important issues seemed to be also important for professional journalists. At the same time, Polish journalists identify themselves to some extent with the indicators of the infotainment model (providing entertainment and relaxation, or concentration on news that's of interest to the widest possible audience). Interestingly, the journalists-to-be seem to be quite similar to professional journalists regarding role perception. They perceive indicators of the disseminator and adversarial model of journalism as the most important roles of the media. However, this group is less internally coherent than professionals - in many cases data on SD reveals a high diversity in the students' answers.

\section{CONCLUSIONS}

The systematic review of the findings of the studies conducted in last four decades revealed several shifts in Polish journalism. First of all, the demographic profile of journalists in Poland has changed: there are more women in the profession and more journalists hold a university degree, while around one third of them graduated from any university program in journalism. The level of academization of journalism in Poland may increase in future, since journalism programs seem to be very popular among young people and around half of current students of Journalism and Social Communication programs consider pursuing a career as journalists.

Secondly, current journalists (and journalism students) are more focused on their own individual careers than on the organizational affairs than journalists in the 1970s and 1980s. The significant change in motivations took place in the late 1980s and early 1990s with the political and economic transition. In the 1970s journalists were almost equally driven by personal aspects such as varied and lively work and more idealistic aspects such as a chance to help people in their everyday life. They were aware of the limitations regarding opportunities of travelling and 
a low level of the prestige of journalism as a profession. In the 2000s they started to believe more in their ability to influence public affairs and criticize and fight problems, as well as in the amount of autonomy they have. At the same time personal and practical aspects of the job became more important to Polish journalists.

Finally, in the last four decades, professional values of journalism in Poland have been slightly shifting from a traditional profile of a social educator and watchdog to new ones, such as a news provider. Not surprisingly, the most significant change in role perceptions occurred in the 1990s with new market-oriented media organizations entering the Polish media system.

\section{REFERENCES}

Anikina, M. (2015). Ideals and values of modern journalists: The search for balance. In: Nygren, G., Dobek-Ostrowska, B. (eds.). Journalism in Change. Journalistic Culture in Poland, Russia and Sweden. Frankfurt am Main: Peter Lang, pp. 153-178.

Bajka, Z. (1991). Dziennikarze (1981-1990). Komunikowanie masowe w Polsce - lata osiemdziesiąte [Journalists (1981-1990). Mass communication in Poland in the 1980s]. Zeszyty Prasoznawcze, 1-2, pp. 149-159.

Bajka, Z. (2000). Dziennikarze lat dziewięćdziesiątych [Journalists of the 1990s]. Zeszyty Prasoznawcze, 3-4, pp. 42-63.

Balcytiene, A., Lauk, E., Głowacki, M. (2014). Roller coasters of social change, democracy and journalism in Central and Eastern Europe. In: Głowacki, M., Lauk, E., Balcytiene, A. (eds.). Journalism that Matters. Views from Central and Eastern Europe. Frankfurt am Main: Peter Lang, pp. 9-20.

Culbertson, H. (1983). Three Perspectives on American Journalism. Journalism Monographs. No. 83.17.

Curry, J.L. (1980). Polish journalists in the policy-making process. In: Kanet, R. (ed.). Background to Crisis: Policy and Politics in Gierek's Poland. Boulder: Westview Press, pp. 177-198.

Curry, J.L. (1990). Poland's Journalists Professionalism and Politics. Cambridge: Cambridge University Press.

Dobek-Ostrowska, B. (2012). Journalists in Poland - some previous research. In: Journalism in Russia, Poland and Sweden - Traditions, Cultures and Research. Stockholm: Journalistikstudier vid Södertörns Högskola 4, pp. 32-52.

Dobek-Ostrowska, B., Barczyszyn, P., Michel, A. (2013). Zmiana w dziennikarstwie. Kultura zawodowa polskich dziennikarzy (badania ilościowe) [A change in journalism. Professional culture of Polish journalists (quantitative studies). Studia Medioznawcze, 1, pp. 11-28.

Donsbach, W., Patterson, T.E. (2004). Political news journalists: Partisanship, professionalism, and political roles in five countries. In: Esser, F., Pfetsch, B. (eds.). Comparing Political Communication. Theories, Cases, and Challenges. Cambridge: Cambridge University Press, pp. 251-270.

Dziki, S. (2000). Prasa w rozwoju historycznym [Historical development of the press]. In: Bauer, Z., Chudziński, E. (eds.). Dziennikarstwo i świat mediów [Journalism and the Media World]. Kraków: Universitas.

Głowacki, M. (2013). Dziennikarze polscy w świetle studiów porównawczych systemów odpowiedzialności mediów w Europie [Polish journalists in the light of comparative studies on the media accountability systems in Europe]. Studia Medioznawcze, 1 (52), pp. 29-44.

Głowacki, M. (2015). Who is a journalist today? Mapping selected dimensions for comparative study on journalism. In: Nygren, G., Dobek-Ostrowska, B. (eds.). Journalism in Change. Journalistic Culture in Poland, Russia and Sweden. Frankfurt am Main: Peter Lang, pp. 63-96. 
GUS (2013). Szkolnictwo wyższe w Polsce [Higher education in Poland]. Retrieved June 12, 2016 from https://www.nauka.gov.pl/g2/oryginal/2013_07/0695136d37bd577c8ab03 acc5c59a1f6.pdf.

Hanitzsch, T. (2007). Deconstructing journalism culture. Toward a universal theory. Communication Theory, 17 (4), pp. 367-385.

Hanusch, F., Mellado, C. (2014). Journalism students professional views in eight countries. The role of motivations, education, and gender. International Journal of Communication, 8, pp. $1156-$ 1173.

Jakubowicz, K. (1992). From party propaganda to corporate speech? Polish journalism in search of a new identity. Journal of Communication, 42 (3), pp. 64-73.

Lewandowska, S. (1982). Polska konspiracyjna prasa informacyjno-polityczna 1939-1945 [The Polish Underground Press 1939-1945]. Warszawa: Czytelnik.

Łojek, J., Myśliński, J., Władyka, W. (1988). Dzieje prasy polskiej [The History of the Polish Press]. Warszawa: Interpress.

Mellado, C. (2015). Professional roles in news content: Six dimensions of journalistic role performance. Journalism Studies, 4, pp. 596-614.

Mellado, C., Lagos, C. (2014). Professional roles in news content: Analyzing journalistic performance in the Chilean national press. International Journal of Communication, 8, pp. 2090-2112.

Nygren, G., Dobek-Ostrowska, B. (eds.) (2015). Journalism in Change. Journalistic Culture in Poland, Russia and Sweden. Frankfurt am Main: Peter Lang.

Olędzki, J. (1998). Polish journalists: Professionals or not? In: Weaver, D.H. (ed.). The Global Journalist. News People around the World. New Jersey: Hampton Press, Inc., pp. 257-276.

Olszewski, E. (2009). Rozwój studiów politologicznych w uczelniach wyższych [Development of the political science study programs at the universities]. In: Wojtaszczyk, K.A., Mirska, A. (eds.). Demokratyczna Polska w globalizującym się świecie [Democratic Poland in the Globalised World]. Warszawa: Wydawnictwo Akademickie i Profesjonalne, pp. 201-221.

Pisarek, W. (1995). Kwalifikacje dziennikarzy polskich w opinii redaktorów naczelnych [Polish journalists' qualifications in the opinion of editors-in-chief]. Zeszyty Prasoznawcze, 1-2, pp. 153163.

Pisarek, W. (1998). A la recherche des journalist polonais. In: Feigelson, K., Pelissier, N. (eds.). Telerevolutions Culturelles: Chine, Europe Centrale, Russie. Paris: L'Harmattan.

Sonczyk, W. (2001). Zawód dziennikarski w kontekście transformacji polskiego systemu medialnego (wybór problematyki) [Journalism profession in the context of the Polish media system's transformation (selected issues)]. Studia Medioznawcze, 3, pp. 35-45.

Splichal, S., Sparks, C. (1994). Journalists for the 21st Century: Tendencies of Professionalization among First-year Students in 22 Countries. Norwood, NJ: Ablex.

Stępińska, A., Głowacki, M. (2014). Professional roles, context factors and responsibility across generations of Polish journalists. In: Głowacki, M., Lauk, E., Balcytiene, A. (eds.). Journalism that Matters. Views from Central and Eastern Europe. Frankfurt am Main: Peter Lang, pp. 79-96.

Stępińska, A., Ossowski, S. (2010a). Polski dziennikarz - niezależny altruista? [A Polish journalist — an independent altruist?]. In: Machura, W. (ed.). Etyka w mediach [Ethics in Media], vol. 5. Nowe media - stare idee [New media - old ideas]. Poznań and Opole: Wydawnictwo Naukowe Scriptorium, pp. 35-46.

Stępińska, A., Ossowski, S. (2010b). Dziennikarze polscy — między mitem „czwartej władzy” a świadomością misji [Polish journalists - between a myth of the "fourth estate" and an awareness of a mission]. In: Kowalczyk, R., Machura, W. (eds.). Media - czwarta władza? [Media - the fourth estate?]. Poznań and Opole: Wydawnictwo Naukowe Scriptorium, pp. 55-66.

Stępińska, A., Ossowski, S. (2011a). Społeczne oczekiwania a autostereotyp dziennikarzy polskich $\mathrm{w}$ XXI wieku [Social expectations and the autostereotype of the Polish journalists in the 21st century]. In: Pająk-Patkowska, B. (ed.). Stereotypy w obszarze społecznym i politycznym [Stereo- 
types in Social and Political Area]. Poznań: Wydawnictwo Wydziału Nauk Politycznych i Dziennikarstwa UAM, pp. 33-46.

Stępińska, A., Ossowski, S. (2011b). Dziennikarze w Polsce: wartości, priorytety i standardy zawodowe [Polish journalists: values, priorities, and professional standards]. Studia Medioznawcze, 1, pp. 17-30.

Stępińska, A., Ossowski, S. (2011c). Kariera, kontrola, służba społeczna — postawy różnych pokoleń polskich dziennikarzy [Career, control, civic service - attitudes of the Polish journalists' generations]. In: Hoffman, I. (ed.). Studia nad dziennikarstwem [Journalism Studies]. Lublin: Wydawnictwo Uniwersytetu Marii Curie-Skłodowskiej, pp. 43-62.

Stępińska, A., Ossowski, S. (2012). Three generations of Polish journalists: Professional roles and identities. Journalism Studies, 5-6, pp. 857-867.

Stępińska, A., Ossowski, S., Pokrzycka, L., Nowak, J. (2012). The journalists and journalism of Poland. In: Weaver, D.H., Willnat, L. (eds.). The Global Journalist in the 21st Century. New York and London: Routledge, pp. 255-266.

Weaver, D.H. (ed.) (1998). The Global Journalist. News People around the World. New Jersey: Hampton Press, Inc.

Weaver, D.H., Wilhoit, G.C. (1996). The American Journalist in the 1990s: U.S. News People at the End of an Era. Mahwah, NJ: Lawrence Erlbaum Associates.

Weaver, D.H., Willnat, L. (eds.) (2012). The Global Journalist in the 21st Century: News People around the World. New York: Routledge. 